\title{
Determinants of vitamin D status in pregnant fair-skinned women in Sweden
}

\author{
Petra Brembeck*, Anna Winkvist and Hanna Olausson \\ Department of Internal Medicine and Clinical Nutrition, Sablgrenska Academy, University of Gothenburg, Box 459, \\ 40530 Göteborg, Sweden
}

(Submitted 15 June 2012 - Final revision received 2 November 2012 - Accepted 30 November 2012 - First published online 7 February 2013)

\begin{abstract}
Low maternal vitamin D status during pregnancy may have negative consequences for both mother and child. There are few studies of vitamin D status and its determinants in pregnant women living at northern latitudes. Thus, the present study investigates vitamin $\mathrm{D}$ status and its determinants during the third trimester of women living in Sweden (latitudes $57-58^{\circ} \mathrm{N}$ ). A total of ninety-five fair-skinned pregnant women had blood taken between gestational weeks 35 and 37 . The study included a $4 \mathrm{~d}$ food diary and questionnaires on dietary intake, supplement use, sun exposure, skin type, travels to southern latitudes and measure of BMI. Serum 25-hydroxyvitamin D (25(OH)D) was analysed using the chemiluminescence immunoassay. In the third trimester of pregnancy, mean serum concentration of $25(\mathrm{OH}) \mathrm{D}$ was $47.4(\mathrm{sD} 18 \cdot 1) \mathrm{nmol} / \mathrm{l}$ (range $10-93 \mathrm{nmol} / \mathrm{l})$. In total, $65 \%$ of women had serum $25(\mathrm{OH}) \mathrm{D}<50 \mathrm{nmol} / 1$ and $17 \%<30 \mathrm{nmol} / 1$. During the winter, $85 \%$ of the pregnant women had serum $25(\mathrm{OH}) \mathrm{D}<50 \mathrm{nmol} / 1$ and $28 \%<30 \mathrm{nmol} / \mathrm{l}$. The main determinants of vitamin $\mathrm{D}$ status were as follows: season; use of vitamin D supplements; travels to southern latitudes. Together, these explained $51 \%$ of the variation in $25(\mathrm{OH}) \mathrm{D}$. In conclusion, during the winter, the majority of fair-skinned pregnant women had serum $25(\mathrm{OH}) \mathrm{D}<50 \mathrm{nmol} / \mathrm{l}$ in their third trimester and more than every fourth woman $<30 \mathrm{nmol} / \mathrm{l}$. Higher vitamin D intake may therefore be needed during the winter for fairskinned pregnant women at northern latitudes to avoid vitamin D deficiency.
\end{abstract}

Key words: 25-Hydroxyvitamin D: Pregnancy: Dietary intake: Sun exposure

Low vitamin D status has been associated not only with suboptimal bone health, but also with higher frequencies of $\mathrm{CVD}^{(1)}$, type 1 diabetes $^{(2)}$, cancers ${ }^{(3,4)}$, infectious diseases ${ }^{(3)}$, multiple sclerosis ${ }^{(3,5)}$ and psychological conditions such as depression and schizophrenia ${ }^{(6)}$. During pregnancy, vitamin $\mathrm{D}$ deficiency also has been associated with maternal health outcomes, e.g. hypertensive disorders ${ }^{(7)}$, gestational diabetes $^{(5,8)}$ and risk of caesarean section ${ }^{(9)}$. Further, low maternal vitamin D status during pregnancy may have an impact on fetal imprinting ${ }^{(10)}$, increase the risk of low birth weight $^{(11-13)}$ and small-for-gestational age ${ }^{(7,14)}$, and may also effect the child's bone health ${ }^{(15)}$. Exposure of pregnant women and fetuses to high doses of vitamin $\mathrm{D}$ also requires careful attention due to risks of hypercalcaemia and hypercalciuria and other possible adverse effects ${ }^{(16)}$.

A major function for vitamin $\mathrm{D}$ is its role in $\mathrm{Ca}$ and bone metabolism. During pregnancy, the need for $\mathrm{Ca}$ is increased due to the requirement of $\mathrm{Ca}$ to form the fetal skeleton. This may lead to the mobilisation of $\mathrm{Ca}$ from the maternal skeleton $^{(17)}$. We have shown that there is a decrease in whole-body bone mineral content of about $2 \%$ during pregnancy $^{(18)}$. It is not known whether these pregnancy-induced skeletal changes are vitamin D dependent. However, women who are pregnant during the winter, when UVB exposure is low, have higher ultrasound indices of maternal bone loss ${ }^{(19)}$. This may indicate a role for vitamin D. Overall, longitudinal studies have suggested that decreases in maternal bone mineral density during reproduction are transient, with replenishment of skeletal minerals in the later stages of lactation and after lactation has ceased ${ }^{(20)}$. The role for vitamin D in the mineral replenishment process remains to be clarified. Normally, parathyroid hormone (PTH) plays a major role in maintaining $\mathrm{Ca}$ balance, by increasing $\mathrm{Ca}$ release from the skeleton and by increasing $\mathrm{Ca}$ reabsorption from the kidneys ${ }^{(21)}$. During pregnancy, however, the role of PTH is unclear and the inverse relationship between serum PTH and serum $\mathrm{Ca}$ may not be the same as in non-pregnant adults $^{(22)}$. Also, the inverse relationship between PTH and 25-hydroxyvitamin D (25(OH)D) may be weaker in pregnant women $^{(22,23)}$.

Abbreviations: 25(OH)D, 25-hydroxyvitamin D; PAL, physical activity level; PTH, parathyroid hormone.

*Corresponding author: P. Brembeck, fax +46 31786 3101, email petra.brembeck@gu.se 
Vitamin D is partly obtained from the diet and dietary supplements. In Sweden, the major dietary sources of vitamin D are fish, fish-containing foods and dairy products ${ }^{(24)}$. Vitamin $\mathrm{D}$ is also obtained by cutaneous synthesis induced after UVB light exposure ${ }^{(25)}$. Below latitude $35^{\circ} \mathrm{N}$, cutaneous vitamin D synthesis is possible all year ${ }^{(25)}$. In the circulation, $25(\mathrm{OH}) \mathrm{D}$ is the metabolite, which is measured as a proxy for vitamin D status ${ }^{(26-29)}$. Among non-pregnant women, season ${ }^{(30)}$, skin pigmentation ${ }^{(31)}, \mathrm{BMI}^{(25,30)}$ and dietary intake, e.g. fatty fish $^{(32)}$ and vitamin D supplement use ${ }^{(33)}$, have been shown to be associated with serum $25(\mathrm{OH}) \mathrm{D}$. For pregnant women, determinants of $25(\mathrm{OH}) \mathrm{D}$ are less understood, but are known to include season and ethnicity ${ }^{(12,34-37)}$. Lifestyle factors such as sun exposure, supplement use and dietary intake of vitamin D have not been well studied. However, a recent Belgian study reported significant determinants of serum $25(\mathrm{OH}) \mathrm{D}$ during pregnancy to include sunscreen use, preference for shadow and holidays to sunny climates, as well as vitamin D supplement use, ethnicity, alcohol use, smoking and education ${ }^{(38)}$.

Studies measuring the vitamin D status of pregnant women in Western societies have found mean concentrations of $25(\mathrm{OH}) \mathrm{D}$ between 26 and $98 \mathrm{nmol} / \mathrm{l}^{(12,14,23,34,38-43)}$. Many of these studies were conducted at latitudes where cutaneous production of vitamin $\mathrm{D}$ is possible for most of the year. Low serum 25(OH)D in pregnant dark-skinned women has been reported in several studies ${ }^{(23,41,44,45)}$. Less is known about vitamin $\mathrm{D}$ status and its determinants in pregnant fair-skinned women living in Sweden or at similar northern latitudes. To our knowledge, only a few studies have been published about vitamin D status of pregnant fair-skinned women living at these latitudes ${ }^{(38,42,43,46,47)}$, of which only one has reported the determinants of vitamin $D$ status thoroughly ${ }^{(38)}$. The aims of the present study were to assess vitamin $\mathrm{D}$ status and to evaluate its determining factors during the third trimester of pregnancy in fair-skinned women living in Sweden.

\section{Subjects and methods}

\section{Subjects}

Women were recruited from July 2008 to July 2011 using posters in maternity health care clinics and in public places in the vicinity of Gothenburg, Sweden, and through advertisement on a web page addressing pregnant women in western Sweden. In total, ninety-five pregnant women were recruited. Inclusion criteria were age 25-40 years, pregnancy in gestational weeks $35-37$ when starting the study and to declare oneself as healthy. Exclusion criteria were prescribed medicine intake known to affect $\mathrm{Ca}$ and bone metabolism, pregnancy during the last 1.5 years before the start of the present pregnancy, miscarriage after week 12 of pregnancy during the last 1.5 years, breast-feeding during the last year before the start of the present pregnancy, twin pregnancy and development of gestational diabetes or pre-eclampsia. The present study was conducted according to the guidelines laid down in the Declaration of Helsinki, and all procedures involving human subjects were approved by the Regional Ethics Committee in Gothenburg. Written informed consent was obtained from all women.

\section{Study design}

All women visited the Department of Internal Medicine and Clinical Nutrition, University of Gothenburg, Sweden when they were between 35 and 37 weeks pregnant. Venous blood was drawn in the morning after an overnight fast. Body weight in underwear (Tanita, BWB-800MA; Rex Frederiksbergs Vaegtfabrik) and height (standardised wall stadiometer) were measured. Women were asked what their body weight was before they became pregnant. Hence, prepregnancy BMI is based on self-reported pre-pregnancy body weight and the height measured at the study visit. Women were also asked questions about their medical history, sun exposure, skin type, dietary intake and physical activity. After birth, women were asked to report day of birth, birth weight and birth length.

\section{Methods}

Sun exposure was estimated using questions compiled by Burgaz et $a l .{ }^{(32)}$. These included use of sunscreen (always, sometimes or never) and preference for sun or shade when outdoors in summer (always in the sun, both sun and shade or always in the shade). Women were asked whether they had used a sunbed during the previous 6 months. Skin types were defined using the Fitzpatrick scale ( $\mathrm{I}=$ always burns, never tans, II = usually burns, tans with difficulty, III = sometimes burns mildly, tans gradually, IV = rarely burns, tans easily) ${ }^{(48)}$. Women were asked to estimate the number of hours spent outdoors between 09.00 and 18.00 hours on weekdays, weekends, summer and winter, respectively. Weekdays corresponded to working days and weekends to nonworking days. Summer was defined as May-October and winter as November-April. Women were also asked to report travels to southern latitudes during the previous 6 months. Southern latitude was defined as a location below latitude $35^{\circ} \mathrm{N}$ where cutaneous synthesis of vitamin D is possible all year round ${ }^{(25)}$.

Dietary intake of vitamin D was estimated using $4 \mathrm{~d}$ food diaries. Women were asked to record all food and drink consumed as precisely as possible on four consecutive days with at least one non-working day and a preferred start no later than 1 week after the study visit. Both oral and written information on how to fill in the food diary were given. Women were asked to report the amounts of consumed food items using household measures, weight in grams or using photographs of different portion sizes used in the Swedish portion guide 'Matmallen'(49). Women were also asked not to change their diet. Women were contacted if any ambiguities were noted in their food diaries. Dietary intake was calculated using DietistXP, version 3.1 (The National Food Agency food database version 2009-11-10; Kost och näringsdata). In addition, a short FFQ was also used to study the frequency and quantity of foods rich in vitamin D consumed, e.g. fatty 
fish and dairy products. Specifically, information about the intake of reduced-fat dairy milk and yogurt/sour milk was requested. Details of use, frequency, amount and brand of supplements containing vitamin D were also requested.

Each woman rated her physical activity on a scale between 1 and $10^{(50)}$. Women were informed that 1 indicated a sedentary lifestyle, 5 a few long walks each week and 10 exercise several times per week. The answer was converted to a physical activity level (PAL), where 1 corresponded to PAL 1.3 and 10 to PAL $2 \cdot 2$, respectively. Each step between them represented a 0.1 increase. In a validation study, PAL assessed using this scale was correlated $(r 0.54 ; P=0.008)$ with corresponding estimates obtained using criterion methods (i.e. the doubly labelled water method in combination with indirect calorimetry) in twenty-two healthy Swedish pregnant women (M Löf, personal communication). Here, the individual self-estimated PAL was used for validating energy intake from the $4 \mathrm{~d}$ diary food records and thus for identifying possible under-reporters according to Goldberg et al. ${ }^{(51)}$ and Black ${ }^{(52)}$. No correction for under-reporting was made. BMR was calculated using the Food and Agriculture Organization/WHO/United Nations University's equation for non-pregnant women ${ }^{(53)}$, and a general increase in BMR of $24 \%$ for pregnant women in their third trimester was added as suggested by Butte \& King ${ }^{(54)}$.

\section{Laboratory analyses}

Blood samples were protected from UVB light and centrifuged no later than $45 \mathrm{~min}$ after sampling at $5^{\circ} \mathrm{C}, 3800 \mathrm{~g}$, for $9 \mathrm{~min}$ (Centrifuge CR3i; Jouan Quality System). Serum was then aliquoted and stored at $-70^{\circ} \mathrm{C}$ until analysed. The analyses of serum concentrations of $25(\mathrm{OH}) \mathrm{D}$ and PTH were performed by Central Laboratory, Sahlgrenska University Hospital, Gothenburg, Sweden. All samples were analysed at one time. Analyses of total 25(OH)D and 25-hydroxyvitamin $\mathrm{D}_{3}$ were performed in serum with the LIAISON ${ }^{\circledR} 25(\mathrm{OH}) \mathrm{D}$ chemiluminescence immunoassay (DiaSorin). Intact PTH was analysed with an immunochemical two-step analysis of sandwich type, using chemiluminescent microparticle immunoassay technology (Abbott Laboratory Diagnostics Division). Intra-assay $\mathrm{CV}$ were $7 \cdot 3,5.7$ and $5.3 \%$ for $25(\mathrm{OH}) \mathrm{D}$ serum concentrations of 22, 50 and $150 \mathrm{nmol} / \mathrm{l}$, respectively. For PTH, CV were $3.7,4.5$ and $3.5 \%$ for PTH serum concentrations of 10,40 and $730 \mathrm{ng} / \mathrm{l}$, respectively.

\section{Statistical analyses}

Independent sample $t$ tests and ANOVA were used to evaluate the difference in the mean concentration of $25(\mathrm{OH}) \mathrm{D}$ depending on lifestyle and other factors, such as parity, estimates of sun exposure, estimates of vitamin D intake and PTH. Estimates of sun exposure included season, time spent outdoors, recent travels to southern latitudes, skin type, sun preference and sunscreen use, and estimates of vitamin D intake included total intake of vitamin D (from diet and supplements), dietary intake of vitamin $\mathrm{D}$, intake of different food items rich in vitamin D and vitamin D supplement use. The coefficients of determination for $25(\mathrm{OH}) \mathrm{D}$ serum concentrations were calculated using bivariate regression analyses for the following variables: estimates of sun exposure; estimates of vitamin D intake; PAL; body weight; BMI. The variables significant in the bivariate regression analyses were included in the multivariate regression analysis. The effects of interactions between factors on 25(OH)D concentrations were modelled by the inclusion of combinations of sun exposure estimates and vitamin $\mathrm{D}$ intake estimates. In the multivariate regression analysis, a variable was considered a confounder if its inclusion in the model caused $a>10 \%$ change in the coefficient of the slope. However, no potential confounders were found. The significance level was set to $P<0.05$ (two-sided). All analyses were conducted using SPSS Statistics software (version 19.0; IBM).

\section{Results}

Descriptive characteristics for the ninety-five women in their third trimester of pregnancy are shown in Table 1. All women were fair-skinned and lived in western Sweden at latitudes $57-58^{\circ} \mathrm{N}$. Their mean age was 32.2 years and $14 \%$ of the women had $\mathrm{BMI} \geq 25 \mathrm{~kg} / \mathrm{m}^{2}$ before becoming pregnant. The mean self-reported pre-pregnancy body weight was $64 \mathrm{~kg}$ and the mean body-weight gain until the third trimester was $13 \mathrm{~kg}$. Parity ranged from 0 to 2 and half of the women were nulliparous. All women gave birth to full-term healthy babies with a mean birth weight of 3581 (SD 477) $\mathrm{g}$ and a mean birth length of 50 (SD 2) cm. Of these, $80 \%$ had studied for three or more years at university. None of the women was current smokers and only one was using snuff.

The mean serum concentration of $25(\mathrm{OH}) \mathrm{D}$ was $47 \cdot 4$ (SD 18.1) nmol/1 (range 10-93 nmol/l) (Fig. 1). Concentrations of serum $25(\mathrm{OH}) \mathrm{D}<30,<50$ and $<75 \mathrm{nmol} / 1$ were found in 17,65 and $92 \%$ of the women, respectively. During the winter, $85 \%$ of women had serum $25(\mathrm{OH}) \mathrm{D}<50 \mathrm{nmol} / \mathrm{l}$ and $28 \% \mathrm{had}$ concentrations $<30 \mathrm{nmol} / \mathrm{l}$. However, during the summer, $41 \%$ of women had $25(\mathrm{OH}) \mathrm{D}$ concentrations $<50 \mathrm{nmol} / 1$ and only $2 \% \mathrm{had}<30 \mathrm{nmol} / \mathrm{l}$. The mean serum concentration of $25(\mathrm{OH}) \mathrm{D}$ was $>50 \mathrm{nmol} / \mathrm{l}$ only from June to September (Fig. 2). Serum concentrations of $25(\mathrm{OH}) \mathrm{D}$ were highest during the summer, with the highest mean in August

Table 1. Characteristics of the ninety-five pregnant women living in Sweden

(Mean values and $95 \%$ confidence intervals)

\begin{tabular}{|c|c|c|}
\hline Characteristics & Mean & $95 \% \mathrm{Cl}$ \\
\hline Age (years) & $32 \cdot 8$ & $32 \cdot 1,33 \cdot 5$ \\
\hline Gestational week in the third trimester & $35 \cdot 7$ & $35.5,35.9$ \\
\hline Height (cm) & $168 \cdot 9$ & $167 \cdot 6,170 \cdot 2$ \\
\hline Weight before pregnancy $(\mathrm{kg})$ & $64 \cdot 3$ & $62 \cdot 7,65 \cdot 9$ \\
\hline Weight in the third trimester $(\mathrm{kg})$ & $77 \cdot 3$ & $75 \cdot 3,79 \cdot 3$ \\
\hline Weight gain at the third trimester $(\mathrm{kg})$ & 13 & $12 \cdot 1,13 \cdot 9$ \\
\hline BMI before pregnancy $\left(\mathrm{kg} / \mathrm{m}^{2}\right)$ & $22 \cdot 5$ & $22 \cdot 0,23 \cdot 0$ \\
\hline Infant birth weight $(\mathrm{g})$ & 3581 & 3485,3677 \\
\hline Infant birth length $(\mathrm{cm})^{*}$ & 50 & 49,52 \\
\hline Gestational length $(\mathrm{d}) \dagger$ & 281 & 276,286 \\
\hline
\end{tabular}




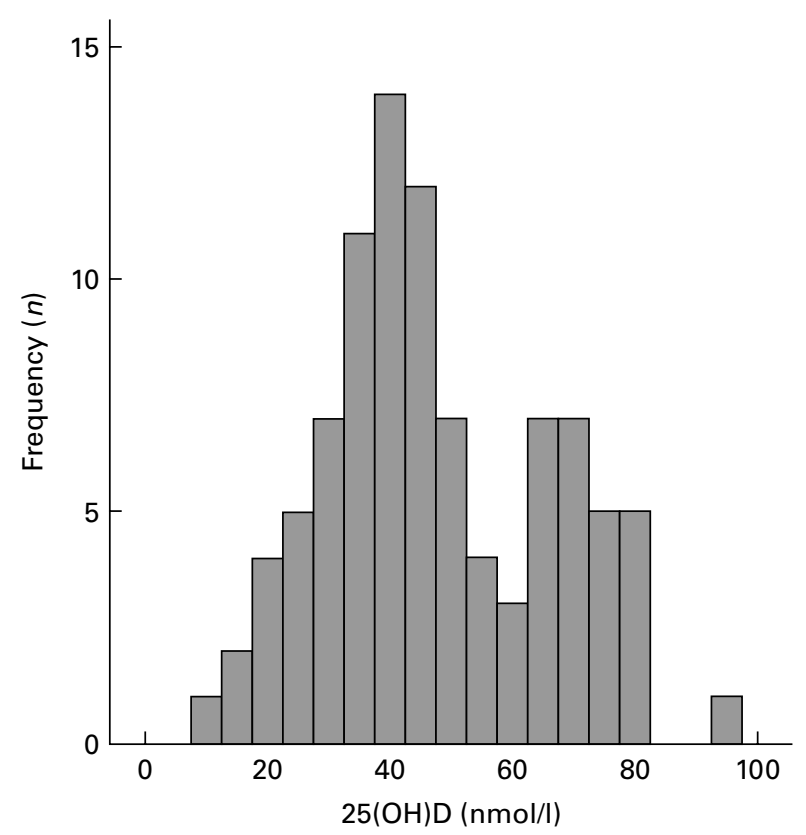

Fig. 1. Distribution of serum concentrations of 25 -hydroxyvitamin $D(25(\mathrm{OH}) \mathrm{D})$ in the third trimester of pregnancy $(n$ 95). Mean 47.4 (SD 18.1) nmol/l.

$(69 \mathrm{nmol} / \mathrm{l})$. The lowest concentrations were seen in late winter and April had the lowest mean (33 nmol/1). The mean serum concentration was $53 \%$ higher in the summer compared with winter. The difference in serum $25(\mathrm{OH}) \mathrm{D}$ between summer and winter was highly significant $(P<0 \cdot 001)$.

The mean dietary intake of vitamin D was $6 \cdot 1 \mu \mathrm{g} / \mathrm{d}$ and the mean total intake of vitamin $\mathrm{D}$ (from diet and supplements) was $9.3 \mu \mathrm{g} / \mathrm{d}$. Data from the FFQ on the dietary intake of vitamin D-rich foods are shown in Table 2. No association was seen between serum concentrations of $25(\mathrm{OH}) \mathrm{D}$ and dietary vitamin $\mathrm{D}$ intake or the intake of food rich in vitamin $\mathrm{D}$, such as fatty fish or dairy products. A trend was seen between the intake of low-fat yogurt and sour milk and serum concentrations of $25(\mathrm{OH}) \mathrm{D}(P=0 \cdot 08)$. More than half of the women $(56 \%)$ were taking supplements containing vitamin D, and for these women, the mean vitamin D supplement intake was $5.8 \mu \mathrm{g} / \mathrm{d}$ and the total vitamin D intake was $12.0 \mu \mathrm{g} / \mathrm{d}$. The mean serum concentration of $25(\mathrm{OH}) \mathrm{D}$ was $46 \%$ higher among women taking supplements containing vitamin D, compared with those who did not $(P<0 \cdot 001)$. A significant association was found between the total vitamin $D$ intake (from diet and supplements) and serum concentrations of 25(OH)D ( $P=0 \cdot 008)$. Body weight and BMI were not associated with serum $25(\mathrm{OH}) \mathrm{D}$ concentrations.

The mean self-estimated PAL was 1.6 (SD 0.2) (range $1 \cdot 3-2 \cdot 2)$. The mean food intake level (energy intake:BMR) was 1.3 (SD 0.2) (range 0.8-1.8). No association was seen between PAL and serum 25(OH)D. When validating energy intake $v$. PAL, $24 \%$ of the subjects were identified as underreporters.

Sun exposure and other lifestyle variables potentially related to $25(\mathrm{OH}) \mathrm{D}$ concentrations are shown in Table 3. Women who preferred to stay in the sun when outdoors during the summer had $21 \%$ higher mean serum concentrations of $25(\mathrm{OH}) \mathrm{D}$ compared with women who preferred to stay in the shade or who preferred a mix of sun and shade $(P=0 \cdot 03)$. The median times spent outdoors during the summer were $2 \mathrm{~h}$ during weekdays and $4 \mathrm{~h}$ during week-

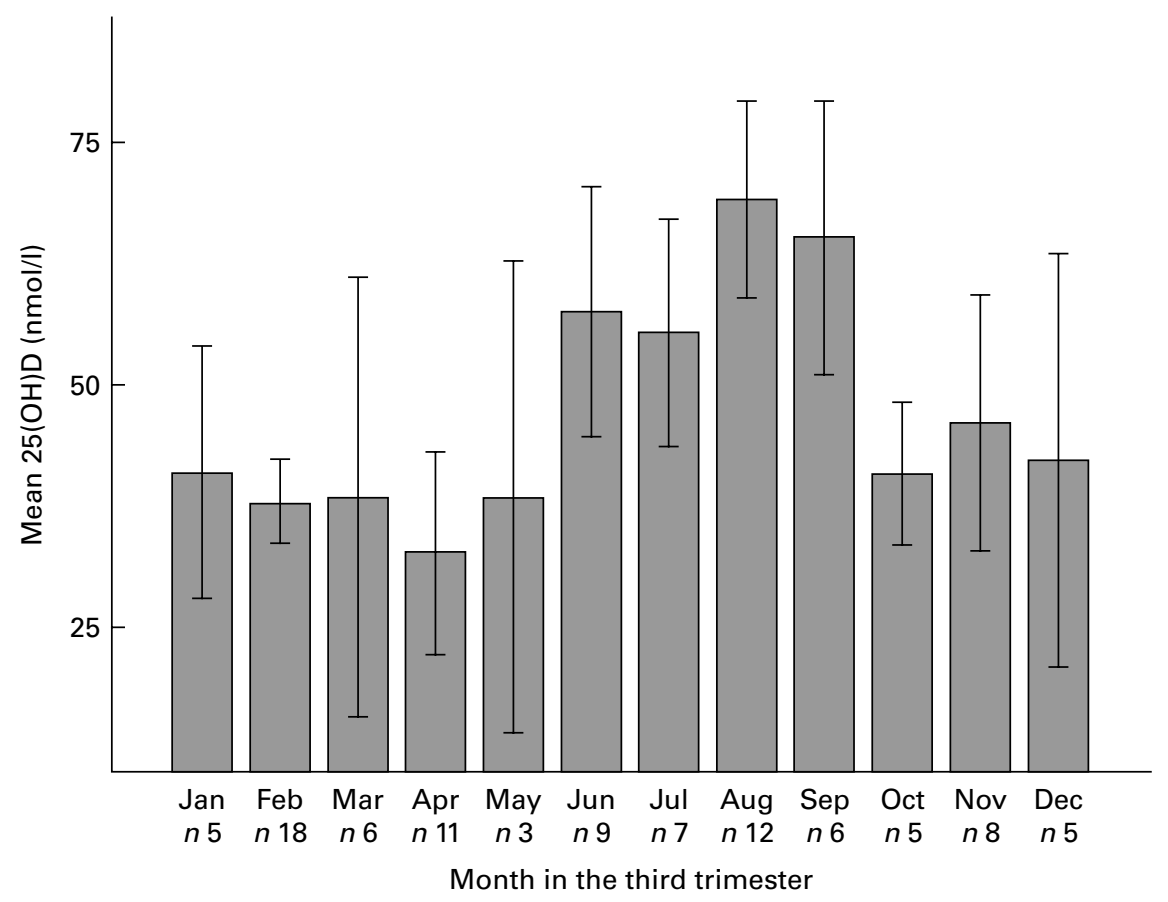

Fig. 2. Monthly mean 25-hydroxyvitamin D $(25(\mathrm{OH}) \mathrm{D})$ in the third trimester of pregnancy $(n 95)$. Values are means, with $95 \% \mathrm{Cl}$ represented by vertical bars. A significant difference was seen between the winter and summer months $(P<0.001)$. 
Table 2. Dietary vitamin D intake from the $4 \mathrm{~d}$ food record and the intake of vitamin D-rich foods and supplements from the FFQ (Mean values and $95 \%$ confidence intervals, $n$ 95)

\begin{tabular}{lcc}
\hline Dietary intake & Mean & $95 \% \mathrm{Cl}$ \\
\hline Dietary vitamin D intake $(\mu \mathrm{g} / \mathrm{d})^{*}$ & $6 \cdot 1$ & $5 \cdot 5,6 \cdot 7$ \\
Fatty fish $(\mathrm{g} / \mathrm{week}) \dagger$ & 110 & 93,127 \\
Total milk intake $(\mathrm{ml} / \mathrm{d}) \dagger$ & 220 & 181,259 \\
Low-fat milk $(\mathrm{ml} / \mathrm{d}) \dagger$ & 197 & 161,233 \\
Total yogurt/sour milk intake $(\mathrm{ml} / \mathrm{d}) \dagger$ & 168 & 145,190 \\
Low-fat yogurt/sour milk $(\mathrm{ml} / \mathrm{d}) \dagger$ & 82 & 58,106 \\
Spread $(\mathrm{g} / \mathrm{d}) \dagger$ & 18 & 14,22 \\
Vitamin D supplement intake $(\mu \mathrm{g} / \mathrm{d}) \dagger$ & $3 \cdot 3$ & $2 \cdot 6,4 \cdot 0$ \\
Vitamin D supplement intake $(\mu \mathrm{g} / \mathrm{d}) \dagger \ddagger$ & $5 \cdot 8$ & $5 \cdot 0,6 \cdot 6$ \\
\hline
\end{tabular}

* From the $4 \mathrm{~d}$ food record.

†From the FFQ.

$\ddagger$ Supplement users only ( $n$ 53).

ends. During the winter, the median time spent outdoors was 1 and $2 \mathrm{~h}$, respectively. Serum 25(OH)D was not associated with the time spent outdoors, either during the summer or winter. In addition, no association was seen between serum $25(\mathrm{OH}) \mathrm{D}$ and skin type. However, subjects who more frequently used sunscreen tended to have higher serum 25(OH)D $(P=0 \cdot 07)$. Also, a positive relationship was found between time spent outdoors during the summer and the use of sunscreen $(P=0.013$ for non-working days and $P=0.031$ for working days). None of the women had used a sunbed in the last 6 months.

Of the subjects, $18 \%$ had travelled to southern latitudes during the past 6 months. Mean serum concentration of $25(\mathrm{OH}) \mathrm{D}$ was $35 \%$ higher in this group compared with women who had not travelled to southern latitudes $(P=0.001)$. During the winter, $25 \%$ of the women had neither recently travelled to southern latitudes nor taken vitamin D supplements. These women had a mean serum 25(OH)D of $30 \mathrm{nmol} / 1$, which was significantly lower than for those who used vitamin D supplements and/or had travelled to southern latitudes $(P<0 \cdot 001)$.

The mean concentration of PTH was 43.8 (SD 15.6) ng/l. A significant inverse association was seen between serum concentrations of $25(\mathrm{OH}) \mathrm{D}$ and PTH $(P=0.008, r-0.271$; Table 4$)$. Women with serum $25(\mathrm{OH}) \mathrm{D}<50 \mathrm{nmol} / 1 \mathrm{had}$ significantly higher serum PTH (47.1 (SD 16.1) ng/l), compared with women with serum $25(\mathrm{OH}) \mathrm{D}>50 \mathrm{nmol} / \mathrm{l}$ (37.7 (sD $12 \cdot 9) \mathrm{ng} / \mathrm{l})(P=0 \cdot 005)$. The mean serum PTH was significantly higher during the winter than during the summer $(P=0 \cdot 011)$.

No association was seen between the maternal serum concentration of $25(\mathrm{OH}) \mathrm{D}$ and infant birth weight or birth length. However, a negative relationship was seen between PTH and birth weight $(P=0.03 ; \beta=-6.06$ (SD 2.72)). A significant positive association was found between serum $25(\mathrm{OH}) \mathrm{D}$ and maternal height $(P=0.010)$, parity $(P=0.050)$ and sex of the baby, where mothers giving birth to boys had higher serum 25(OH)D ( $P=0 \cdot 006)$.

Multivariate regression analyses showed that the major factors determining the concentration of $25(\mathrm{OH}) \mathrm{D}$ were season, use of vitamin D supplements and travels to southern latitudes. Together, these factors explained $51 \%$ of the variation in serum 25(OH)D (Table 5).

\section{Discussion}

The strengths of the present study are the wide range of possible determinants of vitamin D status studied, including detailed measures of vitamin D intake from diet and supplements separately, several estimates of sun exposure and investigations of seasonal variation in $25(\mathrm{OH}) \mathrm{D}$. Previous studies in pregnant women have found an association between serum concentrations of 25(OH)D and season $^{(34-36,38,43)}$, ethnicity or skin type ${ }^{(34-36,38,44)}$, total vitamin D intake ${ }^{(34)}$, supplement use ${ }^{(36,38,41)}$, education ${ }^{(38)}$, smoking and alcohol use $\mathrm{e}^{(38)}$, and sun exposure ${ }^{(34,36,38,43)}$. None of these studies included, however, measurements of vitamin D intake from diet and supplements separately, and only a Belgian national survey included different estimates of sun exposure $^{(38,43)}$

The mean $25(\mathrm{OH}) \mathrm{D}$ in the present study was lower than means reported previously in fair-skinned pregnant women at similar latitudes, e.g. Sweden ${ }^{(47)}$ and Denmark ${ }^{(42)}$, and similar to those reported in Caucasian Belgian pregnant women $^{(38,43)}$. Despite similar latitudes and ethnicity, differences in vitamin D status between studies may depend on trimester, season of blood sampling and the method used for $25(\mathrm{OH}) \mathrm{D}$ analysis. It must be remembered that there is no 'gold standard' for measuring 25(OH)D. The chemiluminescence immunoassay used in the present study has been shown to give lower serum concentrations of $25(\mathrm{OH}) \mathrm{D}$, compared with high-pressure liquid chromatographyatmospheric pressure chemical ionisation-MS ${ }^{(55)}$.

Table 3. Lifestyle factors and 25-hydroxyvitamin D (25(OH)D) concentrations of the ninety-five pregnant women during the third trimester, living in Sweden

(Mean values, number of subjects and percentages)

\begin{tabular}{lrrl}
\hline Lifestyle factors & $n$ & $\%$ & Mean $25(\mathrm{OH}) \mathrm{D}(\mathrm{nmol} / \mathrm{l})$ \\
\hline Parity & & & \\
0 & 49 & 52 & $50 \cdot 8$ \\
1 & 35 & 37 & $44 \cdot 5$ \\
2 & 11 & 12 & $41 \cdot 2$ \\
Sunscreen use & & & \\
$\quad$ Never & 4 & 4 & $30 \cdot 7$ \\
$\quad$ Sometimes & 58 & 62 & $46 \cdot 9$ \\
$\quad$ Always & 32 & 33 & $50 \cdot 8$ \\
Preference of sun or shade & & & \\
$\quad$ Sun & 22 & 23 & $54 \cdot 8^{\star}$ \\
$\quad$ Shade or sun and shade & 72 & 76 & $45 \cdot 3$ \\
Skin type† & & & \\
$\quad$ I & 3 & 3 & $45 \cdot 0$ \\
$\quad$ II & 18 & 19 & $43 \cdot 6$ \\
$\quad$ III & 64 & 67 & $48 \cdot 1$ \\
$\quad$ IV & 10 & 11 & $50 \cdot 6$ \\
Travels to southern latitudes $\ddagger$ & & & \\
$\quad$ Yes & 17 & 18 & $60 \cdot 2^{\star *}$ \\
$\quad$ No & 78 & 82 & $44 \cdot 6$ \\
Use of vitamin D supplements & & & \\
$\quad$ Yes & 53 & 56 & $55 \cdot 1^{\star \star *}$ \\
$\quad$ No & 42 & 44 & $37 \cdot 7$ \\
\hline
\end{tabular}

Mean values were significantly different from the rest of the group: ${ }^{*} P<0.05$, ${ }^{\star *} P<0.01,{ }^{* \star \star} P<0.001$.

$\dagger I$, always burns, never tans; II, usually burns, tans with difficulty; III, sometimes burns mildly, tans gradually; IV, rarely burns, tans easily.

¥Travels to latitude $35^{\circ} \mathrm{N}$ or below, during the last 6 months before the measurements. 
Table 4. Parathyroid hormone (PTH) concentrations related to the different levels of 25-hydroxyvitamin $\mathrm{D}(25(\mathrm{OH}) \mathrm{D})$ of the ninety-five pregnant women during the third trimester, living in Sweden (Number of subjects, percentages and $95 \%$ confidence intervals)

\begin{tabular}{lcccc}
\hline $25(\mathrm{OH}) \mathrm{D}(\mathrm{nmol} / \mathrm{l})$ & $n$ & $\%$ & $\mathrm{PTH}(\mathrm{ng} / \mathrm{l})$ & $95 \% \mathrm{Cl}$ \\
\hline$<30$ & 16 & 17 & $49 \cdot 4$ & $41 \cdot 1,57 \cdot 7$ \\
$30-49 \cdot 9$ & 46 & 48 & $46 \cdot 3$ & $41 \cdot 6,51 \cdot 0$ \\
$\geq 50$ & 33 & 35 & $37 \cdot 7$ & $33 \cdot 3,42 \cdot 1$ \\
Total & 95 & 100 & $43 \cdot 8$ & $40 \cdot 7,46 \cdot 9$ \\
\hline
\end{tabular}

Sunscreen use tended to be positively associated with serum $25(\mathrm{OH}) \mathrm{D}$. This is probably explained by the positive association also found between sun preference and serum $25(\mathrm{OH}) \mathrm{D}$ and the finding that women who spent more time outdoors during the summer were significantly more frequent sunscreen users. Sunscreen use, therefore, seems to rather reflect time spent outdoors in the sun than its inhibiting effect on endogenous vitamin D production. Possibly, a higher number of subjects would give more power to find a significant positive relationship between sunscreen use and serum 25(OH)D, especially since the Belgian national survey also reported that women using sunscreen lotion had a significant lower risk of severe vitamin D deficiency ${ }^{(38)}$.

During the winter, UVB-mediated production of vitamin D is absent at northern latitudes ${ }^{(25)}$. Accordingly, a majority of the women in the present study had serum 25(OH)D $<50 \mathrm{nmol} / 1$ during this period. Additionally, women who had travelled to southern latitudes below latitude $35^{\circ} \mathrm{N}$ within the previous 6 months or preferred to stay in the sun in the summertime had significantly higher concentrations of $25(\mathrm{OH}) \mathrm{D}$. This confirms similar findings in the Belgian survey in pregnant women ${ }^{(38)}$. A study of Swedish elderly women also found similar relationships ${ }^{(32)}$.

Both the mean dietary intake of vitamin D $(6 \cdot 1 \mu \mathrm{g} / \mathrm{d})$ and the mean total intake of vitamin $\mathrm{D}(9.3 \mu \mathrm{g} / \mathrm{d}$; from diet and supplements) in the present study were lower than the recommended daily intake from the Swedish National Food Agency and the Nordic Nutrition Recommendations $(10 \mu \mathrm{g} / \mathrm{d}$ for pregnant women $)^{(56,57)}$ and the Institute of Medicine from $2010(15 \mu \mathrm{g} / \mathrm{d}$ for adults, including pregnant women $)^{(58)}$. However, the mean dietary intake in the present study was similar to that reported for women of the same age group of $6 \cdot 2 \mu \mathrm{g} / \mathrm{d}$ in the new Swedish national survey from $2011^{(24)}$. The mean total intake of vitamin $\mathrm{D}$ in the present study was somewhat higher than that reported for adult women at all ages (mean $7 \cdot 0 \mu \mathrm{g} / \mathrm{d}$ including supplements) ${ }^{(59)}$. This may partly be explained by the fact that the women in the present study were in the third trimester of pregnancy and may have a higher energy intake than non-pregnant and non-lactating women. When adding vitamin $\mathrm{D}$ intake from diet and supplements, only $39 \%$ of the women in the present study had a total vitamin D intake of $\geq 10 \mu \mathrm{g} / \mathrm{d}$ and only $12 \%$ $\geq 15 \mu \mathrm{g} / \mathrm{d}$. However, when considering vitamin D intake from diet alone, only $9 \%$ had a vitamin $\mathrm{D}$ intake of $\geq 10 \mu \mathrm{g} / \mathrm{d}$ and only $1 \% \geq 15 \mu \mathrm{g} / \mathrm{d}$.

The significant association found between the total intake of vitamin D and serum 25(OH)D is in agreement with previous studies in pregnancy ${ }^{(34,36,60)}$. This association was mainly explained by the strong association between vitamin D supplement intake and $25(\mathrm{OH}) \mathrm{D}$ concentrations. A trend was, however, seen between the intake of reduced-fat yogurt and sour milk and concentrations of $25(\mathrm{OH}) \mathrm{D}$.

Of the total subjects, $24 \%$ under-reported energy intake, and may potentially have led to under-reporting of dietary vitamin D intake as well. No attempt was made to correct under-reporting. However, removal of under-reporters from data analyses did not change the significance of the results. Also, when under-reporters were removed from data analyses, no significant association was seen between the dietary intake of vitamin $\mathrm{D}$, or food items rich in vitamin $\mathrm{D}$, and serum $25(\mathrm{OH}) \mathrm{D}$. The percentage of women under-reporting energy intake is consistent with the results from earlier studies of pregnant women. For example, we have previously shown the percentage of under-reporting among Indonesian women during the third trimester to be $17 \cdot 6 \%{ }^{(61)}$, whereas an Irish study found the proportion of under-reporting in gestational week 14 to be up to $45 \%{ }^{(62)}$. Both studies found high BMI and low education to be important predictors for under-reporting ${ }^{(61,62)}$.

One limitation of the present study is that the women included may not be representative for the whole Swedish population of pregnant women. Of these subjects in the present study, $80 \%$ had three or more years of education at university level, which is a higher number than among women in the same age group in the general population

Table 5. Factors predicting the concentrations of 25-hydroxyvitamin $D$ of the ninety-five pregnant women during the third trimester, living in Sweden

\begin{tabular}{|c|c|c|c|c|c|c|c|c|}
\hline \multirow[b]{2}{*}{ Factors } & \multicolumn{4}{|c|}{ Bivariate model } & \multicolumn{4}{|c|}{ Multivariate model } \\
\hline & $\beta$ & SEM & $P$ & $R^{2}$ & $\beta$ & SEM & $P$ & $R^{2}$ \\
\hline Season* & $19 \cdot 40$ & 3.19 & 0.000 & 0.29 & $16 \cdot 25$ & $2 \cdot 76$ & 0.000 & 0.51 \\
\hline Vitamin D supplement† & $17 \cdot 34$ & 3.31 & 0.000 & 0.23 & 14.06 & $2 \cdot 76$ & 0.000 & \\
\hline Travels to southern latitudes $\ddagger$ & $15 \cdot 57$ & 4.61 & 0.001 & 0.11 & $10 \cdot 17$ & 3.55 & 0.005 & \\
\hline Sun preference§ & 9.50 & 4.34 & 0.031 & 0.05 & 4.26 & 3.23 & 0.190 & \\
\hline
\end{tabular}

Coding for each variable is shown below within parentheses.

* (1) Winter (November-April) or (2) summer (May-October)

$\dagger(1)$ No or (2) yes.

$\ddagger$ Travels to latitude $35^{\circ} \mathrm{N}$ or below, during the last 6 months; (1) no or (2) yes.

$\S(1)$ Shade or sun and shade, or (2) sun. 
$(37 \%)^{(63)}$. Additionally, only $14 \%$ had a BMI $\geq 25 \mathrm{~kg} / \mathrm{m}^{2}$ before entering pregnancy, compared with $37 \%$ of the pregnant women in the same region ${ }^{(64)}$. Thus, the women in the present study were leaner, highly educated and, possibly, more health conscious than pregnant women in general. The interpretation of these results needs therefore to be made with some caution. However, despite the high education and normal body weight, the majority of the subjects had concentrations of $25(\mathrm{OH}) \mathrm{D}<50 \mathrm{nmol} / \mathrm{l}$. Thus, it may be speculated that even lower concentrations of $25(\mathrm{OH}) \mathrm{D}$ are expected in the general population of pregnant women living in Sweden, especially in pregnant women with high pigmentation and those wearing concealing clothing. The Belgian national survey showed that vitamin D deficiency was threeto sixfold higher among women of Asian, African or Hispanic descent when compared with Caucasians ${ }^{(38)}$. More targeted screening surveys on vitamin D status in pregnant women in Sweden and in other countries are needed to confirm this.

At present, there are no general recommendations for optimal vitamin D levels. According to the latest guidelines from the Institute of Medicine, serum concentrations of $25(\mathrm{OH}) \mathrm{D}$ $\geq 50 \mathrm{nmol} / 1$ are recommended ${ }^{(58)}$. The recommendation is based on the importance of vitamin $\mathrm{D}$ for bone health ${ }^{(58)}$. Among non-pregnant adults, a negative relationship is seen between serum PTH and serum $25(\mathrm{OH}) \mathrm{D}^{(65-67)}$, and that above $50 \mathrm{nmol} / \mathrm{l}$ of serum $25(\mathrm{OH}) \mathrm{D}$, there is no further increase in serum $\mathrm{PTH}^{(66)}$. We also found that serum $\mathrm{PTH}$ was significantly higher at serum concentrations of $25(\mathrm{OH}) \mathrm{D}$ below $50 \mathrm{nmol} / \mathrm{l}$. A weaker association between serum PTH and serum 25(OH)D has previously been found among pregnant women ${ }^{(22,23,40,68)}$. A seasonal variation in serum PTH, with highest serum concentrations of PTH during the winter, was also found. This is in agreement with a Danish study of non-pregnant adults ${ }^{(30)}$. However, whether PTH is a marker for determining adequate vitamin D status during pregnancy needs further evaluation. A specific cut-off for serum $25(\mathrm{OH}) \mathrm{D}$ may be needed for pregnant women, due to the plasma volume expansion during pregnancy ${ }^{(69)}$ and possible health benefits of maternal vitamin D status for the mother, fetus and child ${ }^{(70)}$. However, more research is needed to evaluate the importance of vitamin D status during pregnancy for such outcomes ${ }^{(70)}$ and to determine what serum levels of $25(\mathrm{OH}) \mathrm{D}$ should be considered as appropriate during pregnancy.

There is an ongoing discussion on whether or not to recommend supplementation of vitamin $\mathrm{D}$ to all pregnant women $^{(70)}$. It is not clear what dose of vitamin D is required during pregnancy to have an effect on maternal or paediatric outcome. Supplementation with $25 \mu \mathrm{g} / \mathrm{d}$ may be needed to maintain maternal serum concentrations of at least $50 \mathrm{nmol} / \mathrm{l}^{(70)}$. This corresponds with the findings of Cashman et al. ${ }^{(33)}$, where a daily intake of $28.0 \mu \mathrm{g}$ for non-pregnant adults was needed to maintain serum $25(\mathrm{OH}) \mathrm{D}$ concentrations $>50 \mathrm{nmol} / \mathrm{l}$ during the winter.

In conclusion, during the winter, the majority of fair-skinned pregnant women had serum $25(\mathrm{OH}) \mathrm{D}<50 \mathrm{nmol} / 1$ in their third trimester, at latitudes $57-58^{\circ} \mathrm{N}$. In addition, more than every fourth women was vitamin $\mathrm{D}$ deficient during the winter. The main determinants for vitamin D status were season, use of vitamin D supplements and travels to southern latitudes. Thus, also fair-skinned pregnant women at northern latitudes are at risk of vitamin D deficiency, especially during the winter. Higher vitamin D intake may therefore be needed during the winter for pregnant women at these latitudes to maintain $25(\mathrm{OH}) \mathrm{D}$ serum concentrations $>50 \mathrm{nmol} / \mathrm{l}$ and to avoid maternal vitamin $\mathrm{D}$ deficiency.

\section{Acknowledgements}

We would like to thank all women volunteers. We would also like to thank research nurse Anna Folino and laboratory assistants Elisabeth Gramatkovski and Birgitha Arvidsson for their valuable help with the data collection and laboratory work, and Marie Löf for the discussion about the validation of the physical activity scale. The present study was supported by the Graduate School Environment and Health, Martina and Wilhelm Lundgrens Foundation, Hvitfeldtska Foundation, Magnus Bergvall Foundation, Fredrik and Ingrid Thuring Foundation and the Swedish Research Council Formas. P. B. is the main author but all authors contributed to the text. P. B. and H. O. made substantial contribution to the data collection and laboratory work, and P. B., A. W. and H. O. to the statistical analyses. There is no conflict of interest to declare.

\section{References}

1. Giovannucci E, Liu Y, Hollis BW, et al. (2008) 25-Hydroxyvitamin $\mathrm{D}$ and risk of myocardial infarction in men: a prospective study. Arch Intern Med 168, 1174-1180.

2. Mohr SB, Garland CF, Gorham ED, et al. (2008) The association between ultraviolet $\mathrm{B}$ irradiance, vitamin $\mathrm{D}$ status and incidence rates of type 1 diabetes in 51 regions worldwide. Diabetologia 51, 1391-1398.

3. Holick MF (2004) Vitamin D: importance in the prevention of cancers, type 1 diabetes, heart disease, and osteoporosis. Am J Clin Nutr 79, 362-371.

4. Grant WB (2006) Lower vitamin-D production from solar ultraviolet-B irradiance may explain some differences in cancer survival rates. J Natl Med Assoc 98, 357-364.

5. Lapillonne A (2010) Vitamin D deficiency during pregnancy may impair maternal and fetal outcomes. Med Hypotheses $\mathbf{7 4 ,}$ $71-75$.

6. Humble MB, Gustafsson S \& Bejerot S (2010) Low serum levels of 25-hydroxyvitamin D (25-OHD) among psychiatric out-patients in Sweden: relations with season, age, ethnic origin and psychiatric diagnosis. J Steroid Biochem Mol Biol 121, 467-470.

7. Bodnar LM, Catov JM, Simhan HN, et al. (2007) Maternal vitamin D deficiency increases the risk of preeclampsia. $J$ Clin Endocrinol Metab 92, 3517-3522.

8. Clifton-Bligh RJ, McElduff P \& McElduff A (2008) Maternal vitamin D deficiency, ethnicity and gestational diabetes. Diabet Med 25, 678-684.

9. Merewood A, Mehta SD, Chen TC, et al. (2009) Association between vitamin D deficiency and primary cesarean section. J Clin Endocrinol Metab 94, 940-945.

10. Hollis BW \& Wagner CL (2006) Vitamin D deficiency during pregnancy: an ongoing epidemic. Am J Clin Nutr 84, 273. 
11. Mannion CA, Gray-Donald K \& Koski KG (2006) Association of low intake of milk and vitamin D during pregnancy with decreased birth weight. CMAJ 174, 1273-1277.

12. Bowyer L, Catling-Paull C, Diamond T, et al. (2009) Vitamin $\mathrm{D}, \mathrm{PTH}$ and calcium levels in pregnant women and their neonates. Clin Endocrinol (Oxf) 70, 372-377.

13. Viljakainen HT, Saarnio E, Hytinantti T, et al. (2010) Maternal vitamin D status determines bone variables in the newborn. J Clin Endocrinol Metab 95, 1749-1757.

14. Leffelaar ER, Vrijkotte TG \& van Eijsden M (2010) Maternal early pregnancy vitamin D status in relation to fetal and neonatal growth: results of the multi-ethnic Amsterdam Born Children and their Development cohort. Br J Nutr 104, 108-117.

15. Javaid MK, Crozier SR, Harvey NC, et al. (2006) Maternal vitamin D status during pregnancy and childhood bone mass at age 9 years: a longitudinal study. Lancet 367, 36-43.

16. Roth DE (2011) Vitamin D supplementation during pregnancy: safety considerations in the design and interpretation of clinical trials. J Perinatol 31, 449-459.

17. Kovacs CS (2001) Calcium and bone metabolism in pregnancy and lactation. J Clin Endocrinol Metab 86, 2344-2348.

18. Olausson H, Laskey MA, Goldberg GR, et al. (2008) Changes in bone mineral status and bone size during pregnancy and the influences of body weight and calcium intake. Am J Clin Nutr 88, 1032-1039.

19. Javaid MK, Crozier SR, Harvey NC, et al. (2005) Maternal and seasonal predictors of change in calcaneal quantitative ultrasound during pregnancy. J Clin Endocrinol Metab 90, 5182-5187.

20. Olausson H, Goldberg G, MA L, et al. (2012) Calcium economy in human pregnancy and lactation. Nutr Res Rev 25, 40-67.

21. Correale M (2012) Parathyroid hormone measurement in chronic kidney disease - an evolving issue for the nephrologist and the clinical laboratorist: minireview. Immunopharmacol Immunotoxicol 34, 541-547.

22. Wagner CL \& Hollis BW (2011) Beyond PTH: assessing vitamin D status during early pregnancy. Clin Endocrinol (Oxf) 75, 285-286.

23. Haddow JE, Neveux LM, Palomaki GE, et al. (2011) The relationship between PTH and 25-hydroxy vitamin D early in pregnancy. Clin Endocrinol (Oxf) 75, 309-314.

24. Amcoff E, Edberg A, Enghardt Barberi H, et al. (2012) Riksmaten 2010-11. Livsmedels- och näringsintag bland vuxna $i$ Sverige. Resultat från matvaneundersökning utförd 2010-11 (Food and Nutrient Intake among Adults in Sweden. Results from Dietary Survey Performed 2010-11). Uppsala: National Food Agency.

25. Tsiaras WG \& Weinstock MA (2011) Factors influencing vitamin D status. Acta Derm Venereol 91, 115-124.

26. Specker BL (1994) Do North American women need supplemental vitamin $\mathrm{D}$ during pregnancy or lactation? $\mathrm{Am} \mathrm{J}$ Clin Nutr 59, 484S-490S, discussion 490S-491S.

27. Holick MF (2007) Vitamin D deficiency. N Engl J Med 357, 266-281.

28. Borradale D \& Kimlin M (2009) Vitamin D in health and disease: an insight into traditional functions and new roles for the 'sunshine vitamin'. Nutr Res Rev 22, 118-136.

29. Grant WB \& Boucher BJ (2011) Requirements for vitamin D across the life span. Biol Res Nurs 13, 120-133.

30. Thuesen B, Husemoen L, Fenger M, et al. (2012) Determinants of vitamin $D$ status in a general population of Danish adults. Bone 50, 605-610.

31. Nessvi S, Johansson L, Jopson J, et al. (2011) Association of 25-hydroxyvitamin $\mathrm{D}_{3}$ levels in adult New Zealanders with ethnicity, skin color and self-reported skin sensitivity to sun exposure. Photochem Photobiol 87, 1173-1178.

32. Burgaz A, Akesson A, Oster A, et al. (2007) Associations of diet, supplement use, and ultraviolet $\mathrm{B}$ radiation exposure with vitamin D status in Swedish women during winter Am J Clin Nutr 86, 1399-1404.

33. Cashman KD, Hill TR, Lucey AJ, et al. (2008) Estimation of the dietary requirement for vitamin $\mathrm{D}$ in healthy adults. Am J Clin Nutr 88, 1535-1542.

34. Dror DK, King JC, Durand DJ, et al. (2011) Association of modifiable and nonmodifiable factors with vitamin $\mathrm{D}$ status in pregnant women and neonates in Oakland, CA. $J \mathrm{Am}$ Diet Assoc 111, 111-116.

35. Li W, Green TJ, Innis SM, et al. (2011) Suboptimal vitamin D levels in pregnant women despite supplement use. Can J Public Health 102, 308-312.

36. Perampalam S, Ganda K, Chow KA, et al. (2011) Vitamin D status and its predictive factors in pregnancy in 2 Australian populations. Aust N Z J Obstet Gynaecol 51, 353-359.

37. Young BE, McNanley TJ, Cooper EM, et al. (2012) Vitamin D insufficiency is prevalent and vitamin D is inversely associated with parathyroid hormone and calcitriol in pregnant adolescents. J Bone Miner Res 27, 177-186.

38. Vandevijvere S, Amsalkhir S, Van Oyen H, et al. (2012) High prevalence of vitamin D deficiency in pregnant women: a national cross-sectional survey. PLoS One 7, e43868.

39. Salle BL, Delvin EE, Lapillonne A, et al. (2000) Perinatal metabolism of vitamin D. Am J Clin Nutr 71, 1317S-1324S

40. Morley R, Carlin JB, Pasco JA, et al. (2006) Maternal 25-hydroxyvitamin D and parathyroid hormone concentrations and offspring birth size. J Clin Endocrinol Metab 91, 906-912.

41. Madar AA, Stene LC \& Meyer HE (2009) Vitamin D status among immigrant mothers from Pakistan, Turkey and Somalia and their infants attending child health clinics in Norway. Br J Nutr 101, 1052-1058.

42. Milman N, Hvas A \& Berghold T (2012) Vitamin D status during normal pregnancy and postpartum. A longitudinal study in 141 Danish women. J Perinatal Med 40, 57-61.

43. Vercruyssen J, Jacquemyn Y \& Ajaji M (2012) Effect of sun exposure and 25-hydroxyvitamin D status among pregnant women in Antwerpen, Belgium. Int J Gynecol Obstetr 116, 78-86.

44. van der Meer IM, Karamali NS, Boeke AJ, et al. (2006) High prevalence of vitamin D deficiency in pregnant non-Western women in The Hague, Netherlands. Am J Clin Nutr 84, $350-353$, quiz $468-359$.

45. Farrant HJ, Krishnaveni GV, Hill JC, et al. (2009) Vitamin D insufficiency is common in Indian mothers but is not associated with gestational diabetes or variation in newborn size. Eur J Clin Nutr 63, 646-652.

46. O'Riordan MN, Kiely M, Higgins JR, et al. (2008) Prevalence of suboptimal vitamin D status during pregnancy. Ir Med J 101, 242-243.

47. Saaf M, Fernell E, Kristiansson F, et al. (2011) Severe vitamin D deficiency in pregnant women of Somali origin living in Sweden. Acta Paediatr 100, 612-614.

48. Astner S \& Anderson RR (2004) Skin phototypes 2003. J Invest Dermatol 122, xxx-xxxi.

49. National Food Agency (1997) Matmallen (Food Picture Book). Uppsala: National Food Agency.

50. Bexelius C, Lof M, Sandin S, et al. (2010) Measures of physical activity using cell phones: validation using criterion methods. J Med Internet Res 12, e2.

51. Goldberg GR, Black AE, Jebb SA, et al. (1991) Critical evaluation of energy intake data using fundamental principles of 
energy physiology: 1 . Derivation of cut-off limits to identify under-recording. Eur J Clin Nutr 45, 569-581.

52. Black AE (2000) Critical evaluation of energy intake using the Goldberg cut-off for energy intake:basal metabolic rate. A practical guide to its calculation, use and limitations. Int J Obes Relat Metab Disord 24, 1119-1130.

53. FAO (2001) Human Energy Requirements: Report of a Joint FAO/WHO/UNU Expert Consultation. Food and Nutrition Technical Report Series no. 1. Rome: FAO.

54. Butte NF \& King JC (2005) Energy requirements during pregnancy and lactation. Public Health Nutr 8, 1010-1027.

55. Snellman G, Melhus H, Gedeborg R, et al. (2010) Determining vitamin D status: a comparison between commercially available assays. PLoS One 5, e11555.

56. Nordic Nutrition Recommendations (2004) Integrating Nutrition and Physical Activity. Copenhagen: Norden, Nordic Council of Ministers.

57. National Food Agency (2011) Rekommenderat intag av vitaminer och mineraler (Recommended intake of vitamins and minerals). http://www.slv.se/sv/grupp1/Mat-och-naring/ Svenska-narings-rekommendationer/Rekommenderat-intagav-vitaminer-och-mineraler/ (accessed 31 January 2012).

58. Ross AC, Taylor C, Yaktine AL, et al. (2011) Dietary Reference Intakes for Calcium and Vitamin D. Washington, DC: National Academies Press.

59. Pearson M, Nälsén C, Ridefelt P, et al. (2012) Vitamin D status in Swedish adults in Riksmaten 2010. In Nordic Nutrition Conference, Reykjavik, Iceland.

60. Holmes VA, Barnes MS, Alexander HD, et al. (2009) Vitamin $\mathrm{D}$ deficiency and insufficiency in pregnant women: a longitudinal study. Br J Nutr 102, 876-881.

61. Winkvist A, Persson V \& Hartini TN (2002) Underreporting of energy intake is less common among pregnant women in Indonesia. Public Health Nutr 5, 523-529.
62. McGowan CA \& McAuliffe FM (2012) Maternal nutrient intakes and levels of energy underreporting during early pregnancy. Eur J Clin Nutr 66, 906-913

63. Statistics Sweden. (2011) Befolkningens utbildning (Population education). http://www.scb.se/Pages/ProductTables 9575.aspx

64. The National Board of Health and Welfare (2011) Graviditeter, förlossningar och nyfödda barn (Pregnancies, births and newborns). http://www.socialstyrelsen.se/Lists/ Artikelkatalog/Attachments/18267/2011-3-19.pdf （accessed 31 January 2012).

65. Landin-Wilhelmsen K, Wilhelmsen L, Wilske J, et al. (1995) Sunlight increases serum $25(\mathrm{OH})$ vitamin D concentration whereas $1,25(\mathrm{OH})_{2} \mathrm{D}_{3}$ is unaffected. Results from a general population study in Goteborg, Sweden (The WHO MONICA Project). Eur J Clin Nutr 49, 400-407.

66. Lips P (2004) Which circulating level of 25-hydroxyvitamin D is appropriate? J Steroid Biochem Mol Biol 89-90, 611-614.

67. Holick MF (2006) High prevalence of vitamin D inadequacy and implications for health. Mayo Clin Proc 81, 353-373.

68. Hamilton SA, McNeil R, Hollis BW, et al. (2010) Profound vitamin $\mathrm{D}$ deficiency in a diverse group of women during pregnancy living in a sun-rich environment at latitude 32 degrees N. Int J Endocrinol 2010, 917428.

69. Faupel-Badger JM, Hsieh CC, Troisi R, et al. (2007) Plasma volume expansion in pregnancy: implications for biomarkers in population studies. Cancer Epidemiol Biomarkers Prev 16, 1720-1723.

70. De-Regil LM, Palacios C, Ansary A, et al. (2012) Vitamin D supplementation for women during pregnancy. The Cochrane Database of Systematic Reviews, issue 2, CD008873. 